\title{
First insight into Mycobacterium tuberculosis genetic diversity in
} Paraguay

\author{
Norma Candia*1, Beatriz Lopez ${ }^{\dagger 2}$, Thierry Zozio ${ }^{\dagger 3}$, Marcela Carrivale ${ }^{\dagger 2}$, \\ Chyntia Diaz $^{\dagger 1}$, Graciela Russomando ${ }^{\dagger 1}$, Nilda J de Romero ${ }^{\dagger 4}$, Juan C Jara ${ }^{\dagger 5}$, \\ Lucia Barrera $^{\dagger 2}$, Nalin Rastogi ${ }^{\dagger 3}$ and Viviana Ritacco ${ }^{\dagger 2}$
}

\begin{abstract}
Address: ${ }^{1}$ Departamento de Biología Molecular, Instituto de Investigaciones en Ciencias de la Salud (IICS), Universidad Nacional de Asunción, Asunción, Paraguay, ${ }^{2}$ Servicio de Micobacterias, Instituto Nacional de Enfermedades Infecciosas, ANLIS "Carlos G. Malbran", Buenos Aires, Argentina, ${ }^{3}$ Unité de la Tuberculose et des Mycobacteries, Institut Pasteur de Guadeloupe, France, ${ }^{4}$ Laboratorio Central de Salud Pública, Asunción, Paraguay and ${ }^{5}$ Programa Nacional de Control de la Tuberculosis, Asunción, Paraguay

Email: Norma Candia* - nccandia@yahoo.es; Beatriz Lopez - bealopez@anlis.gov.ar; Thierry Zozio - tzozio@pasteur-guadeloupe.fr; Marcela Carrivale - carrivale_marcela@yahoo.es; Chyntia Diaz - cdacosta79@yahoo.com; Graciela Russomando - grusso@rieder.net.py; Nilda J de Romero - tuberculosispy@ hotmail.com; Juan C Jara - pnct_py@hotmail.com; Lucia Barrera - lbarrera@anlis.gov.ar;

Nalin Rastogi - nrastogi@pasteur-guadeloupe.fr; Viviana Ritacco - vritacco@anlis.gov.ar

* Corresponding author †Equal contributors
\end{abstract}

Published: 8 August 2007

BMC Microbiology 2007, 7:75 doi:10.1186/147/-2180-7-75
Received: 21 March 2007

Accepted: 8 August 2007

This article is available from: http://www.biomedcentral.com//47/-2/80/7/75

(C) 2007 Candia et al; licensee BioMed Central Ltd.

This is an Open Access article distributed under the terms of the Creative Commons Attribution License (http://creativecommons.org/licenses/by/2.0), which permits unrestricted use, distribution, and reproduction in any medium, provided the original work is properly cited.

\begin{abstract}
Background: We present a picture of the biodiversity of Mycobacterium tuberculosis in Paraguay, an inland South American country harboring 5 million inhabitants with a tuberculosis notification rate of $38 / 100,000$.

Results: A total of 220 strains collected throughout the country in 2003 were classified by spoligotyping into 79 different patterns. Spoligopatterns of 173 strains matched 51 shared international types (SITs) already present in an updated version of SpoIDB4, the global spoligotype database at Pasteur Institute, Guadeloupe. Our study contributed to the database 13 new SITs and 15 orphan spoligopatterns. Frequencies of major $M$. tuberculosis spoligotype lineages in our sample were as follows: Latin-American \& Mediterranean (LAM) 52.3\%, Haarlem 18.2\%, S clade 9.5\%, T superfamily $8.6 \%$, X clade $0.9 \%$ and Beijing clade $0.5 \%$. Concordant clustering by IS6 I 10 restriction fragment length polymorphism (RFLP) and spoligotyping identified transmission in specific settings such as the Tacumbu jail in Asuncion and aboriginal communities in the Chaco. LAM genotypes were ubiquitous and predominated among both RFLP clusters and new patterns, suggesting ongoing transmission and adaptative evolution in Paraguay. We describe a new and successfully evolving clone of the Haarlem 3 sub-lineage, SIT2643, which is thus far restricted to Paraguay. We confirmed its clonality by RFLP and mycobacterial interspersed repetitive unit (MIRU) typing; we named it "Tacumbu" after the jail where it was found to be spreading. One-fifth of the spoligopatterns in our study are rarely or never seen outside Paraguay and one-tenth do not fit within any of the major phylogenetic clades in SpolDB4.
\end{abstract}

Conclusion: Lineages currently thriving in Paraguay may reflect local host-pathogen adaptation of strains introduced during past migrations from Europe. 


\section{Background}

In spite of the wide availability of cost effective interventions for its control, tuberculosis (TB) is still a major global health problem and the leading cause of death from a curable infectious disease [1]. An increasing amount of evidence indicates that Mycobacterium tuberculosis' ability to spread varies from strain to strain and that different strains have different geographical and/or host specificities $[2,3]$.

Since the discovery of DNA polymorphisms in M. tuberculosis, molecular typing of strains has become invaluable for the study of epidemiology of TB [4]. Restriction fragment length polymorphism typing using the insertion element IS6110 as a probe has been applied since the early 1990 s and still is the most reliable method for M. tuberculosis strain differentiation $[5,6]$. The use of additional $M$. tuberculosis genotyping approaches further allows investigators not only to document outbreaks and track epidemics locally, but also to gain an insight into the global migration and expansion of strains $[7,2]$. Several polymerase chain reaction (PCR)-based techniques have been proposed for M. tuberculosis strain typing. The most widely used is spoligotyping, which detects presence or absence of 43 short variable spacer sequences interspersed with direct repeats in the Direct Repeat (DR) region of the chromosome [8]. A more recent approach consists of the analysis of polymorphisms in 12 to 24 loci containing variable number of tandem repeats of Mycobacterial Interspersed Repetitive Units (MIRU) [9]. These two PCR-based methods have been adapted for high-throughput genotyping and combined provide the basis for research on evolutionary genetics of $M$. tuberculosis [10]. The information on M. tuberculosis population diversity gathered so far in global databases provides a robust platform for research on phylogeny and virulence [11]. Ultimately, this knowledge is contributing to the design of rational measures for the control of TB.

Paraguay is an inland South American country with 5.2 million inhabitants and an area of $400,000 \mathrm{~km}^{2}$; it shares borders with Bolivia, Brazil and Argentina [12]. Politically, the country consists of 17 departments, in addition to Asuncion, the capital city. The Paraguay River runs from North to South dividing the territory in two distinct geographical regions with a remarkable difference in population density. The fertile Oriental Region has $160,000 \mathrm{~km}^{2}$ and as many as 31.5 inhabitants per $\mathrm{km}^{2}$. To the northwest is the Chaco, an arid region with a surface of 247,000 $\mathrm{km}^{2}$ and only one inhabitant per $\mathrm{km}^{2}$; its people are mainly settled in sparse aboriginal communities. A total of 2,116 TB cases were reported countrywide in 2003, yielding a case notification rate of 37.8 cases per 100,000 inhabitants. In absolute numbers, most cases occur in Asuncion and the Central Department, its contiguous densely populated area; both are located in the Oriental Region. In the Oriental Region the incidence mirrors the national rate whereas in the Chaco the rate is 3 to 5 times higher. There is considerable under-reporting of TB in Paraguay; the World Health Organization estimates the true incidence in the country as 50-99 cases per 100,000 [13].

In 2002 the National TB Program implemented a project on anti-TB drug resistance surveillance sponsored by WHO/USAID. At that time, mycobacterial culture was seldom performed in the country and case finding was mainly based on acid fast bacilli smear examination of symptomatic patients. The availability of isolates from this project permitted this first-ever strain typing study in Paraguay. This investigation was undertaken to provide both a nationwide view of the M. tuberculosis population structure and a preliminary assessment of the feasibility and usefulness of genotyping for epidemiological purposes in this limited-resource and endemic TB setting.

\section{Results}

\section{Population characteristics}

Of the 220 strains included in the study, 156 (71\%) were isolated from male patients. One hundred forty-six patients $(66 \%)$ were 20 to 50 years old (mean \pm SD: 38.5 \pm 15.7 , range 10-78). Two hundred and sixteen patients (98\%) were native-born; one patient was an immigrant from South Korea; the place of birth was not registered for the remaining three patients, but their demographic data suggested Brazilian origin.

Sixty-seven strains (30\%) were isolated from patients diagnosed in either Asuncion or the Central Department (hereafter referred to jointly as the metropolitan area); $114(52 \%)$ originated from other areas in the Oriental Region and $39(18 \%)$ were obtained from the sparsely populated Chaco. One hundred and eighty-four strains $(84 \%)$ were isolated from newly diagnosed patients and the remaining $36(16 \%)$ from patients previously treated for TB. Thirty-three strains were drug resistant, six of which were multidrug resistant (i.e. resistant at least to rifampicin and isoniazid).

\section{Lineage assignment according to spoligotyping}

The 220 strains were classified into 79 different spoligopatterns that could be assorted in three groups. The first group included 173 strains matching 51 shared international types (SITs, patterns shared by two or more isolates) already present in an updated version of the SpolDB4 database [14]. For these previously described SITs, Table 1 presents the frequencies found in our study as compared to frequencies in the international database at the time of this analysis, as well as their clade denomination. The second group consisted of 32 strains distributed within 13 newly created SITs, as shown in Figure 1. 
Table I: Frequency of 5 I shared spoligotypes (SITs) according to Brudey et al. [14], identifiedin 173 Mycobacterium tuberculosis strains isolated in Paraguay, 2003

\begin{tabular}{|c|c|c|c|c|c|c|c|}
\hline \multirow[t]{2}{*}{ SIT } & \multirow[t]{2}{*}{ Octal Number } & \multicolumn{2}{|c|}{ Strains in this study } & \multicolumn{2}{|c|}{ Strains in SpolDB4 } & \multirow[t]{2}{*}{$\%$ in this study as compared to SpolDB4 } & \multirow[t]{2}{*}{ Lineage } \\
\hline & & $\mathrm{n}$ & $\%$ & $\mathrm{n}$ & $\%$ & & \\
\hline 42 & ا & 40 & 18.2 & 1926 & 4.5 & 2.1 & LAM \\
\hline 391 & 743777607760731 & 21 & 9.5 & 23 & 0.1 & 91.3 & LAM \\
\hline 34 & $77637777776077 \mid$ & 16 & 7.3 & 618 & 1.4 & 2.6 & $S$ \\
\hline 50 & 77777777772077| & 9 & 4.1 & 2128 & 5.0 & 0.4 & Haarlem \\
\hline 93 & $77773760776077 \mid$ & 6 & 2.7 & 267 & 0.6 & 2.2 & LAM \\
\hline 521 & 7777777777606II & 6 & 2.7 & 22 & 0.1 & 27.3 & $\mathrm{~T}$ \\
\hline 52 & 77777777776073| & 4 & 1.8 & 518 & 1.2 & 0.8 & $\mathrm{~T}$ \\
\hline 159 & 7777400|776077| & 4 & 1.8 & 64 & 0.2 & 6.3 & unknown \\
\hline 4 & $00000000776077 \mid$ & 3 & 1.4 & 220 & 0.5 & 1.4 & unknown \\
\hline 53 & |77777777776077 & 3 & 1.4 & 3738 & 8.8 & 0.1 & $\mathrm{~T}$ \\
\hline 177 & 37777760776077 & 3 & 1.4 & 50 & 0.1 & 6.0 & LAM \\
\hline 1356 & 77637777776075। & 3 & 1.4 & 12 & 0.0 & 25.0 & $\mathrm{~S}$ \\
\hline 1827 & 77770360002077| & 3 & 1.4 & 6 & 0.0 & 50.0 & Haarlem \\
\hline 1832 & 17777360776077| & 3 & 1.4 & 14 & 0.0 & 21.4 & LAM \\
\hline 7 & | & 2 & 0.9 & 54 & 0.1 & 3.7 & $\mathrm{~T}$ \\
\hline 33 & 776|7760776077| & 2 & 0.9 & 770 & 1.8 & 0.3 & LAM \\
\hline 36 & |77773777772077 & 2 & 0.9 & 77 & 0.2 & 2.6 & $\mathrm{~T}$ \\
\hline 47 & 17777777402077 & 2 & 0.9 & 1021 & 2.4 & 0.2 & Haarlem \\
\hline 49 & | & 2 & 0.9 & 115 & 0.3 & 1.7 & Haarlem \\
\hline 60 & 77777760776073| & 2 & 0.9 & 178 & 0.4 & I.I & LAM \\
\hline 95 & 77777760756073I & 2 & 0.9 & 30 & 0.1 & 6.7 & LAM \\
\hline 125 & 000000007760731 & 2 & 0.9 & 55 & 0.1 & 3.6 & unknown \\
\hline 737 & 77777760776057| & 2 & 0.9 & 11 & 0.0 & 18.2 & LAM \\
\hline 753 & 47777760776077| & 2 & 0.9 & 16 & 0.0 & 12.5 & LAM \\
\hline 828 & 377777607760731 & 2 & 0.9 & 20 & 0.0 & 10.0 & LAM \\
\hline 1803 & $61777760776077 \mid$ & 2 & 0.9 & 7 & 0.0 & 28.6 & LAM \\
\hline 1 & 000000000003771 & 1 & 0.5 & 5610 & 13.2 & 0.0 & Beijing \\
\hline 2 & 000000004020771 & I & 0.5 & 337 & 0.8 & 0.3 & Haarlem \\
\hline 17 & | & 1 & 0.5 & 473 & I.I & 0.2 & LAM \\
\hline 20 & |67777760776077 & 1 & 0.5 & 588 & $\mathrm{I} .4$ & 0.2 & LAM \\
\hline 56 & 777737770000000 & 1 & 0.5 & 18 & 0.0 & 5.6 & unknown \\
\hline 58 & I7777755776077 & 1 & 0.5 & 119 & 0.3 & 0.8 & unknown \\
\hline 62 & 777777774020731 & 1 & 0.5 & 233 & 0.5 & 0.4 & Haarlem \\
\hline 92 & 70007677776077| & 1 & 0.5 & 328 & 0.8 & 0.3 & $x$ \\
\hline 102 & 77770377776077| & 1 & 0.5 & 56 & 0.1 & 1.8 & unknown \\
\hline 162 & 77777760776067I & I & 0.5 & 17 & 0.0 & 5.9 & unknown \\
\hline 211 & 776|3760776077| & 1 & 0.5 & 63 & 0.1 & 1.6 & LAM \\
\hline 254 & 77776000776077| & 1 & 0.5 & 120 & 0.3 & 0.8 & LAM \\
\hline 393 & I7775777776077 & 1 & 0.5 & 19 & 0.0 & 5.3 & $T$ \\
\hline 397 & 77777760000077| & i & 0.5 & 13 & 0.0 & 7.7 & unknown \\
\hline 439 & 77737677776060 I & I & 0.5 & 3 & 0.0 & 33.3 & $x$ \\
\hline 578 & 63777760776077| & 1 & 0.5 & 27 & 0.1 & 3.7 & LAM \\
\hline 746 & |77777777752077 & 1 & 0.5 & 22 & 0.1 & 4.5 & Haarlem \\
\hline 765 & 77776007776077| & 1 & 0.5 & 7 & 0.0 & 14.3 & LAM \\
\hline 781 & 000000004020731 & 1 & 0.5 & 9 & 0.0 & 11.1 & Haarlem \\
\hline 784 & 17637777776073 & 1 & 0.5 & 39 & 0.1 & 2.6 & S \\
\hline 1063 & 77637777766077| & 1 & 0.5 & 24 & 0.1 & 4.2 & $S$ \\
\hline 1367 & $37773760776077 \mid$ & 1 & 0.5 & 3 & 0.0 & 33.3 & LAM \\
\hline 1610 & 76377760756077| & 1 & 0.5 & 5 & 0.0 & 20.0 & LAM \\
\hline 1892 & 777777660000I7) & I & 0.5 & 5 & 0.0 & 20.0 & unknown \\
\hline 2644 & | & 1 & 0.5 & 3 & 0.0 & 33.3 & Haarlem \\
\hline
\end{tabular}


Five of these new SITs, (2643, 2645, 2647, 2650 and 2654 ) contained strains only identified in this study. Each of the remaining eight newly created SITs involved a single strain in this study matching with a previously orphan strain in SpolDB4. The third group included the remaining 15 strains that did not match with any other spoligopattern in this study nor in SpolDB4 (Table 2).

The frequencies of major M. tuberculosis spoligotype families as defined in the SpolDB4 database [14] ranked in the following order: Latin-American \& Mediterranean (LAM) 52.3\% (115/220), Haarlem 18.2\% (40/220), S clade $9.5 \%(21 / 220)$, an ill-defined T superfamily (not a clade sensu stricto as it is defined by default) $8.6 \%(19 /$ 220), $X$ clade $0.9 \%(2 / 220)$ and Beijing clade $0.5 \%$ (1/ 220). The sole Beijing strain in the study was pansusceptible and had been obtained from a 47 year-old female South Korean immigrant living in Asuncion. Twenty-two $(10.0 \%)$ strains showed patterns that did not fit within any of the major clades described in SpolDB4.

\section{IS6 I I 0 RFLP analysis and epidemiological clustering}

Patterns of the 165 isolates analyzed by IS6110 RFLP contained between four and 19 bands (mean \pm SD: $11 \pm 3$ ). The sole strain showing an RFLP pattern with four bands belonged to the $\mathrm{X}$ lineage (the other strain of the $\mathrm{X}$ lineage in the study was not available for RFLP). One hundred and nineteen distinct RFLP patterns were observed. When only IS6110 RFLP was considered for clustering analysis, 65 isolates were grouped in 19 clusters of 2, 3, 5, 9 and 10 strains. When both RFLP and spoligotype were analyzed together, four RFLP clusters were further split off and five strains were classified as orphan (see Table 3).

Concordant RFLP and spoligotype clustering involved 15/ $30(50 \%), 20 / 54(37 \%)$ and 25/81 (31\%) strains from the Chaco, the metropolitan area and the Oriental Region, respectively. No association was found between clustering and gender (45/122 among males vs. 16/43 among females, $\mathrm{p}=0.88)$, age $(42 / 99<50$ yrs vs. $20 / 66 \geq 50 \mathrm{yrs}$, $\mathrm{p}=1.16)$, treatment history $(10 / 29$ previously treated vs. $47 / 136$ never treated, $\mathrm{p}=0.70)$ or drug resistance $(7 / 29$ with any drug resistance vs. 54/136 with no resistance, $\mathrm{p}$ $=0.17)$. Demographic evidence was consistent with transmission in particular settings such as the Tacumbu jail in Asuncion, indigenous communities in the Chaco, and a single household in the metropolitan area.

Strains harboring the SIT34 of the S clade grouped in the RFLP cluster $C$ together with two other strains harboring rare spoligotypes: an orphan strain (Py87) and a strain of the new SIT 2653 (Py51). These two novel spoligopatterns could be visually considered to be derived from the SIT 34 associated to this RFLP cluster (Figure 1).
Similarly, identical or closely-related RFLP patterns were exhibited by strains classified within each of five new shared spoligotypes identified exclusively in Paraguay. These are SITs 2643 (cluster A), 2647 (cluster O), 2650 (cluster P), 2645 and 2654 (Figure 1). In cluster A, IS6110 RFLP grouped strains of the SIT2643 together with one strain harboring an orphan spoligotype different from but closely related to SIT 2643. Most strains in this cluster (cluster A) had been isolated from inmates in the Tacumbu jail. Apart from these two orphan strains grouped by RFLP in clusters A and C, the remaining 13 strains with orphan spoligotypes did not match with any of approximately 2000 RFLP patterns contained in the database at the Malbran Institute, which gathers patterns from strains isolated in Argentina and other South American countries.

\section{MIRU-VNTR analysis of new spoligopatterns}

Results of MIRU analysis of 30 selected strains with either new SITs or orphan spoligotypes are summarized in Table 2 and Figure 1. MIRU typing confirmed the clonal nature of two of the five newly described SITs restricted so far to Paraguay: SIT 2650-MIT 427 of the LAM lineage and SIT 2643-MIT 182 of the Haarlem lineage. This latter clone is hereafter named "Tacumbu" after the men's correctional facility in Asuncion where it was most frequently found; it included another strain in the same RFLP cluster with an orphan but related spoligopattern (Py95) isolated from another inmate in the same jail (Figure 1).

\section{Discussion}

We present herein a first insight into the biodiversity of the M. tuberculosis epidemic in Paraguay. At the same time, we provide evidence of the suitability of IS6110 RFLP as a genotyping tool for epidemiological studies in the country, either as a stand-alone tool or, still better, in combination with spoligotyping.

Even though the characteristics of the study sample favored phylogenetic rather than epidemiological analysis, RFLP analysis by itself produced a concise picture of TB transmission patterns in Paraguay. In particular, it served to identify transmission in specific settings such as indigenous communities in the Chaco and the Tacumbu jail in Asuncion. The percentage of clustering in different regions was congruent with the respective regional incidence rates, i.e. highest in the Chaco, intermediate in the densely populated metropolitan area, and lowest in the rest of the Oriental Region.

We did not find correlation of clustering with previous TB treatment or drug resistance, suggesting that in Paraguay most patients develop drug resistant TB individually through selective pressure imposed by poorly constructed or inadequately supervised treatment regimens rather 
Table 2: Characteristics of I5 orphan M. tuberculosis strains identified in Paraguay, 2003

\begin{tabular}{|c|c|c|c|c|}
\hline Strain No. & Binary spoligotype (octal number) & RFLP & MIRUs description (MIT) & Lineage \\
\hline Py63 & (777777757560771) & Unique & $213326 \mid 53223$ (unknown) & $\mathrm{T}$ \\
\hline Py204 & (777777661760771) & nd & $124326 \mid 53227(7 \mid)$ & LAM \\
\hline Py240 & 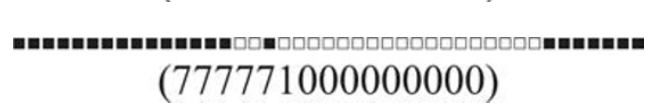 & nd & nd & unknown \\
\hline Pyl33 & (777703600020770) & Unique & 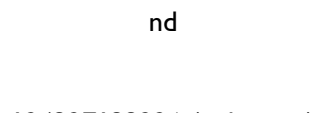 & Haarlem \\
\hline Pyl49 & (777377607760761) & nd & I24327| 33226 (unknown) & LAM \\
\hline Py244 & (777377607760671) & nd & nd & LAM \\
\hline Py20I & (775767760060771) & Unique & 223325153326 (unknown) & unknown \\
\hline Рy91 & (771077607760771) & Unique & I24326|33223 (unknown) & LAM \\
\hline Py21 & (763777607560760) & Unique & $124326 \mid 53224(140)$ & LAM \\
\hline Py59 & (760177777760771) & Unique & *32325I*3322 (unknown) & unknown \\
\hline Py95 & (760147777720771) & Clustered & $225325154323(182)$ & Haarlem \\
\hline РузІ & $(557347607760761)$ & nd & $124326 \mid 53225(427)$ & LAM \\
\hline Py93 & (300777663660711) & Unique & 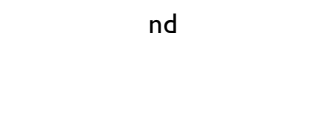 & unknown \\
\hline Py 87 & (000377777560771) & Clustered & $233325153224(218)$ & unknown \\
\hline Pyl36 & 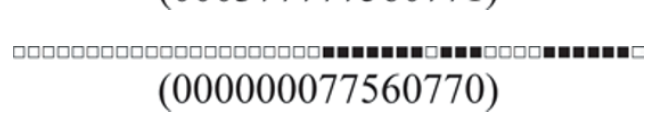 & Unique & nd & unknown \\
\hline
\end{tabular}

than through transmission of resistant strains. The age and gender composition of patients in our sample reflects the predominance of $\mathrm{TB}$ among young male people in Paraguay. This disease distribution is common to many low income settings worldwide and could be attributed to socioeconomic and cultural barriers in the access to health care [15]. In the present study, however, we failed to find association of clustering with gender or age, probably due to the small size of the sample and the short sampling period. In this sense, we are aware of the fact that genotype clustering analysis underestimates transmission and that this bias is inversely proportional to length of time and size of the sample [16].

The relative frequencies of major $M$. tuberculosis spoligotype families were roughly in range with the overall frequencies described for countries in the South American region [14,17-20]. The largely predominant LAM lineage, identified in more than half of the strains in our study, was ubiquitous in the country. Both its high degree of dissemination and its preponderance among the new (shared as well as orphan) patterns are manifestations of the current adaptative evolution of the LAM lineage in 


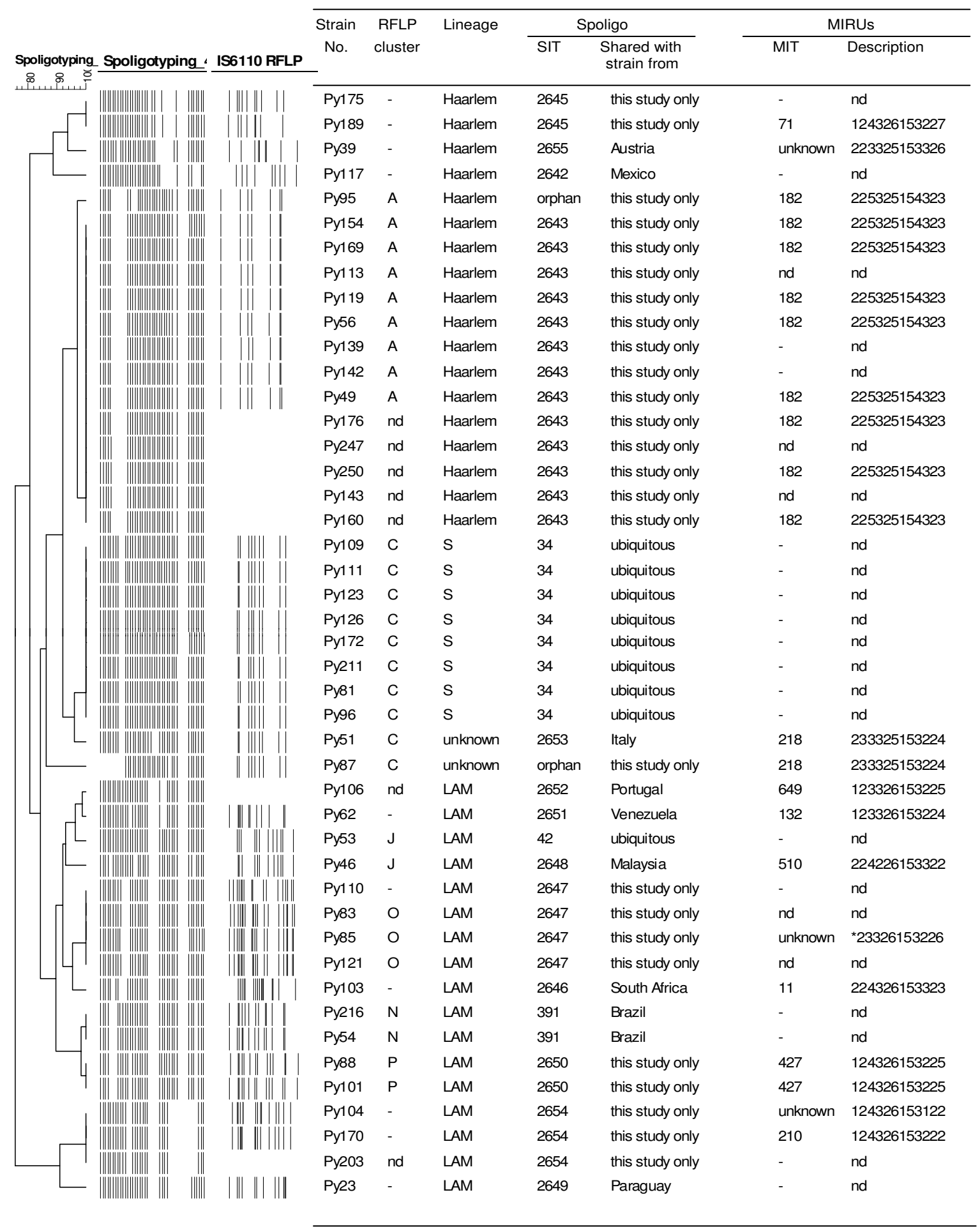

Figure I

Computer-generated dendrogram according to UPGMA spoligotype analysis and characteristics of selected strains from Paraguay, including strains in 13 newly-created shared spoligotypes absent from DB4 and therefore not mentioned in Table I (SITs 2642, 2643, and 2645-2655). 
Table 3: Characteristics of clusters identified by RFLP IS6 I I0 and spoligotyping in Paraguay, 2003

\begin{tabular}{|c|c|c|c|c|c|}
\hline \multirow[t]{2}{*}{ RFLP Cluster } & \multirow[t]{2}{*}{ Size } & \multicolumn{2}{|c|}{ Spoligotype } & \multirow[t]{2}{*}{ Country region $(n)$} & \multirow[t]{2}{*}{ Likely link (n) } \\
\hline & & SIT & Lineage & & \\
\hline \multirow[t]{2}{*}{$A^{*}$} & $9(8)$ & 2643 & Haarlem & Metropolitan Area (7) & $\begin{array}{c}\text { Tacumbu Jail inmates } \\
\text { (6) }\end{array}$ \\
\hline & & & & Oriental (I) & - \\
\hline B & 2 & 49 & Haarlem & Oriental (2) & Undetermined \\
\hline$C^{*}$ & $10(8)$ & 34 & $\mathrm{~S}$ & $\begin{array}{c}\text { Metropolitan Area (2) } \\
\text { Oriental (6) }\end{array}$ & $\begin{array}{l}\text { Undetermined } \\
\text { Neighbor towns (5) }\end{array}$ \\
\hline $\mathrm{D}$ & 3 & 34 & $S$ & Chaco (3) & $\begin{array}{c}\text { Aboriginal community } \\
\text { (3) }\end{array}$ \\
\hline $\mathrm{E}$ & 2 & 34 & $S$ & Oriental (2) & Undetermined \\
\hline \multirow[t]{2}{*}{$\mathrm{F}$} & 2 & 1356 & S & Metropolitan Area (I) & - \\
\hline & & & & Oriental (I) & - \\
\hline \multirow[t]{2}{*}{ G } & 5 & 42 & LAM & Metropolitan Area (4) & Household (3) \\
\hline & & & & Chaco (I) & - \\
\hline \multirow[t]{2}{*}{$\mathrm{H}$} & 3 & 42 & LAM & Metropolitan Area (I) & Tacumbu Jail \\
\hline & & & & Oriental (2) & Undetermined \\
\hline 1 & 2 & 42 & LAM & Metropolitan area (2) & Tacumbu Jail (2) \\
\hline \multirow[t]{2}{*}{$J^{*}$} & $2(0)$ & $\begin{array}{c}42 \\
2648\end{array}$ & LAM & Oriental (2) & Same town (2) \\
\hline & (3) & 42 & LAM & Metropolitan Area (I) & - \\
\hline \multirow[t]{2}{*}{$\mathrm{K}^{*}$} & 5 & & & Oriental (2) & Same department (2) \\
\hline & $(2)$ & 753 & LAM & Oriental (2) & Undetermined \\
\hline $\mathrm{L}$ & 3 & 177 & LAM & Oriental (3) & Same community (2) \\
\hline \multirow[t]{2}{*}{ M } & 3 & 391 & LAM & Metropolitan Area (2) & Undetermined \\
\hline & & & & Chaco (I) & - \\
\hline $\mathrm{N}$ & 2 & 391 & LAM & Chaco (2) & $\begin{array}{c}\text { Aboriginal } \\
\text { communities (2) }\end{array}$ \\
\hline \multirow[t]{2}{*}{ O } & 3 & 2647 & LAM & Oriental (2) & Undetermined \\
\hline & & & & Chaco (I) & - \\
\hline$P$ & 2 & 2650 & LAM & Oriental (2) & Same town (2) \\
\hline Q & 2 & 93 & LAM & Chaco (2) & $\begin{array}{c}\text { Aboriginal community } \\
\text { (2) }\end{array}$ \\
\hline $\mathrm{R}$ & 3 & 52 & $\mathrm{~T}$ & Chaco (3) & $\begin{array}{c}\text { Aboriginal } \\
\text { communities (3) }\end{array}$ \\
\hline S & 2 & 521 & $\mathrm{~T}$ & Chaco (2) & $\begin{array}{c}\text { Aboriginal } \\
\text { communities (2) }\end{array}$ \\
\hline
\end{tabular}

* RFLP clusters marked with an asterisk contain one or more strains with different spoligopattern(s) and numbers in brackets indicate cluster size after subtraction of strains with different spoligopattern.

Paraguay. Second in frequency, the Haarlem clade was found mainly in the metropolitan area. Third in frequency, the $\mathrm{S}$ clade was found predominantly in the Oriental Region. The strains classified within the ill-defined $\mathrm{T}$ family were widely distributed within the country. The IS6110 low-banding pattern X genotype family was rather unusual and the Beijing genotype was absent in the native population of our study. The sole Beijing strain identified in the study was isolated from an East Asian immigrant who most probably acquired her infection prior to arriving in Paraguay.

An example of congruence between phylogenenetic and epidemiological findings is the fact that the four most prevalent SITs in our study accounted for two thirds of the
RFLP/spoligotyping clustered cases, including cases with epidemiological links (e.g., inmates in Tacumbu jail, cases in aboriginal communities, household contacts). These were SIT4 2 of the LAM9 clade, SIT391 of the LAM4 clade, SIT34 of the S clade and the newly-created SIT2643 of the Haarlem clade. As shown by their active ongoing transmission, these SITs could be regarded as highly successful M. tuberculosis genotypes in Paraguay. Interestingly, two of these M. tuberculosis sub-lineages seem to have a restricted geographical distribution: SIT391 has been so far found only in Brazil $(\mathrm{n}=2)$ and Paraguay $(\mathrm{n}=21)$ and the newly created SIT2643 $(n=13)$ is restricted to Paraguay alone. IS6110 RFLP and MIRU typing confirmed the clonality of this latter phylogeographically specific genotype, which is hereby designated as "Tacumbu" genotype. Indeed, this 
clone is completely new as it created not only a new SIT (SIT2643) but also matched a rare MIT (MIT182) in the database within the Haarlem clade.

Although different mutation mechanisms may converge into identical spoligopatterns, the main force driving variation in the DR region appears to be deletion of single or contiguous direct variable repeat sequences [21]. Our data supports this kind of evolution for some actively trasmitting clones, which may represent emerging genotypes in Paraguay. For example, the main chain of transmission in Tacumbu jail included an orphan strain that shared identical MIT and RFLP with other strains in the cluster and harbored a spoligotype that could well have evolved from the same Tacumbu SIT through deletion of two contiguous spacers. Likewise, SIT391, endemic in Paraguay (n:21), has probably evolved to the new SIT2650 $(n=2)$ by the loss of one spacer. Similar deletions in the DR region could have also occurred in two rare strains harboring MIT218 and fitting within the largest RFLP cluster together with 8 strains of the $S$ clade.

In addition to rapid evolution of some predominant strains, spoligotyping revealed the geographical specificity of a number of M. tuberculosis strains in our study. Similar to findings reported in Venezuela, Brazil and Suriname $[17,18,22]$ a number of spoligopatterns in our study were unique among more than 45,000 strains recorded in the SpolDB4. Most of these strains proved further their singularity when tested by RFLP and/or MIRUs. Moreover, almost one in ten strains did not fit into any of the major M. tuberculosis phylogenetic clades described in the updated database and one in five spoligopatterns in the study were rarely or never described outside Paraguay.

\section{Conclusion}

Paraguay's current TB epidemic seems to consist of a wide diversity of sublineages among which a few LAM, Haarlem and $S$ genotypes prevail and are evolving actively. The lineages of tubercle bacilli currently thriving in this rather secluded South American niche may reflect the local hostpathogen adaptation of strains introduced into the country during past migrations from European countries [23].

\section{Methods \\ Clinical isolates}

The 220 M. tuberculosis strains examined in this cross-sectional study were isolated from the same number of patients with pulmonary $\mathrm{TB}$ and positive acid fast bacilli smear examination recruited consecutively during the national survey of drug resistance carried out in Paraguay during 2003. These strains represented $77 \%$ of the 286 strains composing the drug resistance survey, which was designed applying the cluster sampling procedure. The 220 strains of the survey available for genotyping did not differ from those lost to genotyping with respect to drug susceptibility, geographical origin and patient characteristics. Data concerning patient gender, age, geographic origin, date of diagnosis and previous history of TB were collected from the survey questionnaire. Culture was performed on Löwenstein-Jensen slants in five laboratories of the national TB network. Species identification and susceptibility testing to first line anti-TB drugs were performed at the Central Public Health Laboratory of the Ministry of Health using conventional biochemical tests and the standard proportion method on LöwensteinJensen slants [24].

\section{Genotyping}

Chromosomal DNA was prepared by the cetyl-trimethyl ammonium bromide method from heat inactivated bacilli suspensions [25]. Spoligotyping was performed on all 220 isolates by reverse hybridization as described previously [8]. IS6110 restriction fragment length polymorphism (RFLP) was performed according to the standard protocol [26] on the 165 specimens that yielded a sufficient amount of unbroken DNA to successfully perform the protocol. Probe labeling, in the case of RFLP, and detection of hybridizing DNA, in both RFLP and spoligotyping, was done by enhanced chemiluminiscence (ECL kit, Amersham, Little Chalfont, England) followed by exposure to X-ray film (Hyperfilm ECL, Amersham).

The number of repeats of 12 MIRUs (MIRU No. 2, 4, 10, $16,20,23,24,26,27,31,39$ and 40) was investigated on selected isolates by amplification and visual assessment of amplicon size as previously described [27]. PCR mixtures consisted of $0.5 \mu \mathrm{M}$ (each) dNTP (Qbiogene), $2 \mathrm{mM}$ $\mathrm{MgCl}_{2}$ (Amersham), 10\% DMSO, $1 \times$ recombinant Taq buffer mix (Amersham), $0.5 \mathrm{U}$ rTaq (Amersham), $0.3 \mu \mathrm{M}$ each primer and $1 \mu \mathrm{l}$ DNA. The final volume of each reaction was $30 \mu \mathrm{l}$. Samples were amplified in a GeneAmp PCR system 9600 (Perkin Elmer-Applied BiosystemsBasel, Switzerland) by using an amplification profile of 10 min at $94^{\circ} \mathrm{C}, 35$ cycles of $30 \mathrm{~s}$ at $94^{\circ} \mathrm{C}, 60 \mathrm{~s}$ at $60^{\circ} \mathrm{C}$ and 2 min at $72^{\circ} \mathrm{C}$. DNA fragments were separated by electrophoresis on a $1.5 \%$ agarose gel (Invitrogen) and the number of MIRU copies corresponding to the respective bands sizes was then calculated. The tables used for MIRU-VNTR allele scoring are available at [28].

\section{Computer analysis}

Digitalized images of autoradiographs were submitted to computer analysis using the software Bionumerics version 4.0 (Applied Math, Sint-Martens-Latem, Belgium), as described previously [29]. RFLP intra- and inter-experiment normalization was performed using strain Mt14323 DNA as an external marker. Similarity among banding patterns was calculated using the Dice coefficient with $1 \%$ tolerance and $1 \%$ optimization. Clustering analysis was 
performed by the unpaired weight of mathematical averaged method. Clusters were defined as groups of patients infected with $M$. tuberculosis strains showing identical RFLP and spoligopatterns.

Spoligotypes were entered in an updated version of the SpolDB4 database [14]; the unpublished in-house updated version is alternatively termed as SITVIT2 database.

\section{Authors' contributions}

NC carried out the molecular genetic studies, analyzed the data and contributed to drafting the manuscript. BL participated in genotyping studies, analyzed the data and provided suggestions during manuscript preparation. TZ carried out molecular genetic studies, participated in the identification and designation of the SITs and conducted the bioinformatic analysis. MC assisted with data entry and conducted the bioinformatic analysis. CD contributed to the molecular genetic studies, data entry and the review of the manuscript. She also provided technical help in the conservation and management of the strains. GR conceived the study, participated in its design, coordinated the investigation, and provided critical comments to the manuscript. NJR carried out mycobacteriological diagnostics, isolation, identification and drug susceptibility testing of clinical isolates, and provided information about the clinical isolates for molecular study. JCJ participated in the design and carried out the survey of antituberculosis drug-resistance, analyzed the data, and provided the clinical isolates for molecular study. LB participated in the design of the study, and provided critical comments for the manuscript. NR carried out the phylogeny reconstruction studies, participated in the identification and designation of the SITs and also helped in the draft of the manuscript. VR conceived the study and the methodology, coordinated the investigation and wrote the manuscript.

\section{Acknowledgements}

We thank the staff of the Public Health Laboratory and of the National Tuberculosis Program (Paraguayan Ministry of Health) whose collaboration made this work possible.

We are grateful to the Sustainable Science Institute (San Francisco, California, USA) for continuous financial support.

This work was partially supported by projects LSHP-CT-2004-5I6028 of the European Commission, FO-AR 4834/PY of the Argentinean Foreign Office and PICT 05-09978 of SeCyT Argentina, the National University of Asuncion (Asuncion, Paraguay).

TZ benefited from a PhD fellowship partially financed by the European Social Funds provided through the Regional Council of Guadeloupe. VR is a member of the Research Career CONICET, Argentina.

\section{References}

I. Dye C: Global epidemiology of tuberculosis. Lancet 2006, 367:938-940.

2. Filliol I, Motiwala AS, Cavatore M, Qi W, Hazbon MH, Bobadilla del Valle M, Fyfe J, Garcia-Garcia L, Rastogi N, Sola C, Zozio T, Guerrero MI, Leon Cl, Crabtree J, Angiuoli S, Eisenach KD, Durmaz R, Joloba ML, Rendon A, Sifuentes-Osornio J, Ponce de Leon A, Cave MD, Fleischmann R, Whittam TS, Alland D: Global phylogeny of Mycobacterium tuberculosis based on single nucleotide polymorphism (SNP) analysis: insights into tuberculosis evolution, phylogenetic accuracy of other DNA fingerprinting systems, and recommendations for a minimal standard SNP set. J Bacteriol 2006, 188:759-772.

3. Gagneux S, DeRiemer K, Van T, Kato-Maeda M, de Jong BC, Narayanan S, Nicol M, Niemann S, Kremer K, Gutierrez MC, Hilty M, Hopewell PC, Small PM: Variable host-pathogen compatibility in Mycobacterium tuberculosis. Proc Natl Acad Sci USA 2006, 103:2869-2873.

4. Murray M, Nardell E: Molecular epidemiology of tuberculosis: achievements and challenges to current knowledge. Bull World Health Organ 2002, 80(6):477-482.

5. Kremer K, Arnold C, Cataldi A, Gutierrez MC, Haas WH, Panaiotov S, Skuce RA, Supply P, van der Zanden AG, van Soolingen D: Discriminatory power and reproducibility of novel DNA typing methods for Mycobacterium tuberculosis complex strains. J Clin Microbiol 2005, 43:5628-5238.

6. Kremer K, van Soolingen D, Frothingham R, Haas WH, Hermans PW, Martín C, Palittapongarnpim P, Plikaytis BB, Riley LW, Yakrus MA, Musser JM, van Embden JD: Comparison of methods based on different molecular epidemiological markers for typing of Mycobacterium tuberculosis complex strains: interlaboratory study of discriminatory power and reproducibility. I Clin Microbiol 1999, 37:2607-26|8.

7. Filliol I, Driscoll JR, van Soolingen D, Kreiswirth BN, Kremer K, Valetudie G, Dang DA, Barlow R, Banerjee D, Bifani PJ, Brudey K, Cataldi A, Cooksey RC, Cousins DV, Dale JW, Dellagostin OA, Drobniewski F, Engelmann G, Ferdinand S, Gascoyne-Binzi D, Gordon M, Gutierrez MC, Haas WH, Heersma H, Kassa-Kelembho E, Ho ML, Makristathis A, Mammina C, Martin G, Mostrom P, Mokrousov I, Narbonne $\checkmark$, Narvskaya O, Nastasi A, Niobe-Eyangoh SN, Pape JW, RasolofoRazanamparany V, Ridell M, Rossetti ML, Stauffer F, Suffys PN, Takiff $\mathrm{H}$, Texier-Maugein J, Vincent V, de Waard JH, Sola C, Rastogi N: Snapshot of moving and expanding clones of Mycobacterium tuberculosis and their global distribution assessed by spoligotyping in an international study. J Clin Microbiol 2003, 41:1963-1970.

8. Kamerbeek J, Schouls L, Kolk A, van Agterveld M, van Soolingen D, Kuijper S, Bunschoten A, Molhuizen H, Shaw R, Goyal M, van Embden $\mathrm{J}$ : Simultaneous detection and strain differentiation of Mycobacterium tuberculosis for diagnosis and epidemiology. J Clin Microbiol 1997, 35:907-914.

9. Supply P, Lesjean S, Savine E, Kremer K, van Soolingen D, Locht C: Automated high-throughput genotyping for study of global epidemiology of Mycobacterium tuberculosis based on mycobacterial interspersed repetitive units. J Clin Microbiol 200I, 39(10):3563-357I.

10. Supply P, Allix C, Lesjean S, Cardoso-Oelemann M, Rusch-Gerdes S, Willery E, Savine E, de Haas P, van Deutekom H, Roring S, Bifani P, Kurepina N, Kreiswirth B, Sola C, Rastogi N, Vatin V, Gutierrez MC, Fauville M, Niemann S, Skuce R, Kremer K, Locht C, van Soolingen D: Proposal for standardization of optimized mycobacterial interspersed repetitive unit-variable number tandem repeat typing of Mycobacterium tuberculosis. J Clin Microbiol 2006, 44:4498-4510.

II. Streicher EM, Victor TC, van der Spuy G, Sola C, Rastogi N, van Helden PD, Warren RM: Spoligotype signatures in the Mycobacterium tuberculosis complex. J Clin Microbiol 2007, 45:237-240.

12. Dirección General de Estadística, Encuestas y Censos: Atlas Censal del Paraguay Asuncion, Paraguay; 2004.

13. WHO: Global tuberculosis control: surveillance, planning and financing. WHO report 2005. WHO/HTM/TB/2005.349. Geneva; World Health Organization; 2005.

14. Brudey K, Driscoll JR, Rigouts L, Prodinger WM, Gori A, Al-Hajoj SA, Allix C, Aristimuno L, Arora J, Baumanis V, Binder L, Cafrune P, Cataldi A, Cheong S, Diel R, Ellermeier C, Evans JT, Fauville-Dufaux M, Ferdinand S, Garcia de Viedma D, Garzelli C, Gazzola L, Gomes 
HM, Guttierez MC, Hawkey PM, van Helden PD, Kadival GV, Kreiswirth BN, Kremer K, Kubin M, Kulkarni SP, Liens B, Lillebaek T, Ho ML, Martin C, Martin C, Mokrousov I, Narvskaia O, Ngeow YF, Naumann L, Niemann S, Parwati I, Rahim Z, Rasolofo-Razanamparany V, Rasolonavalona T, Rossetti ML, Rüsch-Gerdes S, Sajduda A, Samper S, Shemyakin IG, Singh UB, Somoskovi A, Skuce RA, van Soolingen D, Streicher EM, Suffys PN, Tortoli E, Tracevska T, Vincent V, Victor TC, Warren RM, Yap SF, Zaman K, Portaels F, Rastogi N, Sola C: Mycobacterium tuberculosis complex genetic diversity: mining the fourth international spoligotyping database (SpolDB4) for classification, population genetics and epidemiology. $B M C$ Microbiol 2006, 6:23.

15. Hudelson P: Gender differentials in tuberculosis: the role of socio-economic and cultural factors. Tuber Lung Dis 1996, 77:391-400.

16. Murray M: Sampling bias in the molecular epidemiology of tuberculosis. Emerg Infect Dis 2002, 8:363-369.

17. Aristimuño L, Armengol R, Cebollada A, España M, Guilarte A, Lafoz C, Lezcano MA, Revillo MJ, Martín C, Ramírez C, Rastogi N, Rojas J, de Salas AV, Sola C, Samper S: Molecular characterisation of Mycobacterium tuberculosis isolates in the First National Survey of Anti-tuberculosis Drug Resistance from Venezuela. BMC Microbiol 2006, 6:90.

18. Borsuk S, Dellagostin MM, Madeira Sde G, Lima C, Boffo M, Mattos I, Almeida da Silva PE, Dellagostin OA: Molecular characterization of Mycobacterium tuberculosis isolates in a region of Brazil with a high incidence of tuberculosis. Microbes Infect 2005, 7:1338-1344.

19. Filliol I, Ferdinand S, Sola C, Thonnon J, Rastogi N: Spoligotyping and IS6IIIO -RFLP typing of Mycobacterium tuberculosis from French Guiana: a comparison of results with international databases underlines interregional transmission from neighboring countries. Res Microbiol 2002, 153:8I-88.

20. Mancilla EM, Martinez HA, Palavecino BC, Rehren SG, Lucero LP, Leon RG, Zarraga OAM: Genetic variants of Mycobacterium tuberculosis isolated from patients of the Xth Region of Chile. Rev Chilena Infectol 2006, 23:220-225.

21. Warren RM, Streicher EM, Sampson SL, van der Spuy GD, Richardson M, Nguyen D, Behr MA, Victor TC, van Helden PD: Microevolution of the direct repeat region of Mycobacterium tuberculosis : implications for interpretation of spoligotyping data. J Clin Microbiol 2002, 40:4457-4465.

22. van Crevel R, van Doorninck DJ, van Ams JE, Fat HT, Vreden SG, van der Meer JM: Tuberculosis among Trio-Indians in Surinam. Ned Tijdschr Geneeskd 2004, I 48:425-429.

23. Sola C, Ferdinand S, Sechi LA, Zanetti S, Martial D, Mammina C, Nastasi A, Fadda G, Rastogi N: Mycobacterium tuberculosis molecular evolution in western Mediterranean Islands of Sicily and Sardinia. Infect Genet Evol 2005, 5: I45-156.

24. WHO: Global project on anti-tuberculosis drug resistance surveillance. Guidelines for surveillance of drug resistance in tuberculosis. WHO/TB/2003.320. Geneva; World Health Organization 2003.

25. van Soolingen D, Hermans PW, de Haas PE, Soll DR, van Embden JD: Occurrence and stability of insertion sequences in Mycobacterium tuberculosis complex strains: evaluation of an insertion sequence-dependent DNA polymorphism as a tool in the epidemiology of tuberculosis. I Clin Microbiol 1991, 29:2578-2586

26. van Embden JD, Cave MD, Crawford JT, Dale JW, Eisenach KD, Gicquel B, Hermans P, Martin C, McAdam R, Shinnick TM, Small PM: Strain identification of Mycobacterium tuberculosis by DNA fingerprinting: recommendations for a standardized methodology. J Clin Microbiol I993, 31:406-409.

27. Mazars E, Lesjean S, Banuls AL, Gilbert M, Vincent V, Gicquel B, Tibayrenc $M$, Locht $C$, Supply $P$ : High-resolution minisatellite-based typing as a portable approach to global analysis of Mycobacterium tuberculosis molecular epidemiology. Proc Natl Acad Sci USA 200I, 98:1901-1906.

28. Supply P, Mazars E, Lesjean S, Vincent V, Gicquel B, Locht C: Variable human minisatellite-like regions in the Mycobacterium tuberculosis genome. Mol Microbiol 2000, 36:762-71.

29. Heersma HF, Kremer K, van Embden JD: Computer analysis of IS6II 0 RFLP patterns of Mycobacterium tuberculosis. Methods Mol Biol 1998, I01:395-422.

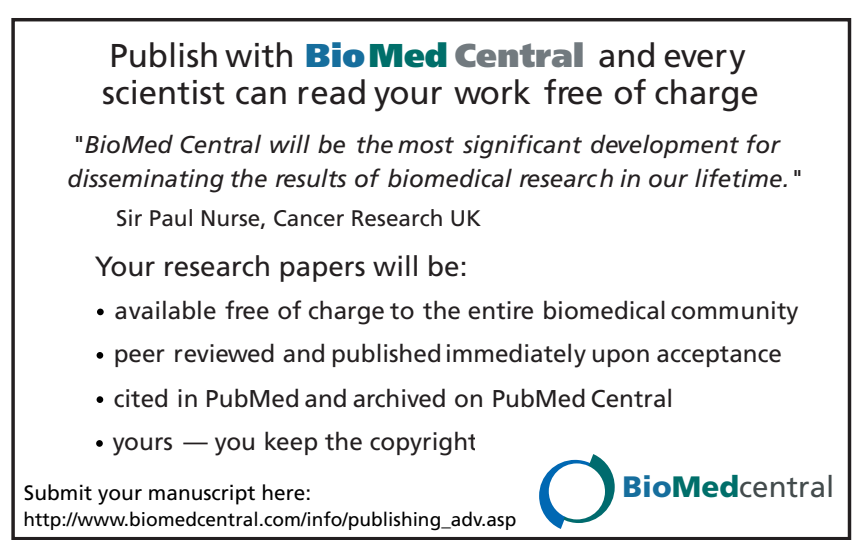

